\title{
اتجاهات طلبة الجامعة نحو
}

مفهوم المواطنة

م. د. حيدر فاضل حسن

مركز البحوث التريوية والنفسية جامعة بذاد - العرلق 



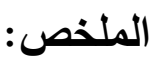

تمثل الاتجاهات نحو مفهوم المواطنة المحصلة لاستجابات الفرد نحو مواضيع منل التقيد بواجباته ومعرفة حقوقه نحو الدولة وفي المجتمع. والبحث الحالي بيهذ الى بناء مقياس لاتجاهات طلبة الجامعة نحو مفهوم المواطنة. وقياس اتجاهات طلبة الجامعة نحو مفهوم المواطنة. والتعرف على الفروق في اتجاهات طلبة الجامعة نحو مفهوم المواطنة على وفق متغيري الجنس والتخصص الدراسي. قام الباحث ببناء مقياس لاتجاهات طلبة الجامعة نحو مفهوم المواطنة ونم تطبيقه على

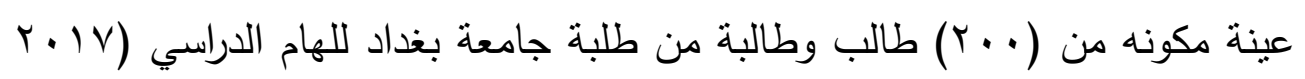

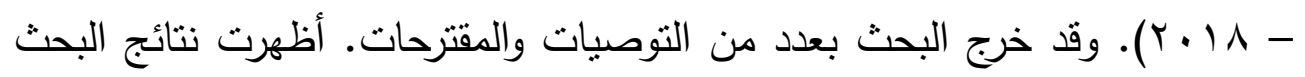
إن لدى طلبة جامعة بغداد اتجاهات إيجابية نحو مفهوم المواطنة. وأنه ليس هناك فروق ذات دلاله في اتجاهات طلبة الجامعة نحو مفهوم المواطنة على وفق متغير الجنس. كما أظهرت النتائج وجود فروق ذات دلالةَ إحصائية في اتجاهات طلبة الجامعة نحو مفهوم المواطنة على وفق متغير التخصص الدراسي؛ إذ إن الطلبة من ذوي التخصص الانساني لديهم اتجاهات أكثر إيجابية نحو مفهوم المواطنة قياساً بالطلبة من ذوي التخصص العلمي.

الكلمات المفتاحية : الاتجاهات ـ مفهوم المواطنة ـ طلبة الجامعة. 


\section{Abstract::}

Attitudes towards the concept of citizenship. Represent the outcome of the individual Responses towards subjects like adhere to duties and knowing of rights, towards country and society. The current research aims to construct a scale for University Students attitudes towards the concept of citizenship, and to measure university students attitudes towards concept of citizenship, and to determine the differences in university students attitudes towards concept of citizenship based on their gender, and specialization. The Researcher constructed a scale for university students attitudes towards concept of citizenship, and it was used on a sample consist of (200) male and female from the Baghdad University Students in (2017-2018) academic year. The results showed that university students had a positive attitude towards the concept of citizenship, and there's no significant difference in university students attitudes towards concept of citizenship based on their gender. But there's a significant difference in university students attitudes towards concept of citizenship based on their specialization, students of humanities specialties had a more positive attitudes towards concept of citizenship compared to the students of scientific specialties. The research came out with several recommendations and proposals.

Key words: attitudes, concept of citizenship, university students. 


\section{الفصل الأول}

مشكلة البحث: - n

تعد المواطنة من المقومات الأساسية للولاء للوطن وللمجتمع وقيمه. وقد مز العراق بالكثير من الاضطرابات والانقسامات أدت الى حدوث تصدعات في بنية المجتمع وفي اتجاهات الأفراد نحو مفهوم المواطنة. وذلك أسهم في الفوضى والعنف اللذين نسبيا في خسارة الكثير من الأرواح والثروات وانحراف البلد عن مسار التتمية الذي يجب أن يسير فيه. وفي وسط كل ذلك تظهر المواطنة وبناء اتجاهات إيجابية نحوها بوصفها تحدياً جديّاً لإعادة بناء/اللحمة الوطنية، من خلال فهم المواطن

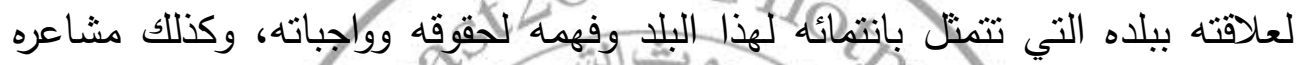
اتجاه بلده؛ إذ يمنل ذللكجموه مهوة لتجاوز الانقسام والولاء للانتماءات الفرعية التي تكون على حساب الانتماء الاوطني الأوسع.

وحيث إن الاتجاهات نحو مفهوم المواطنة تحمل أهمية ويي التكوين النفسي للفرد بوصفه مواطناً في البلا، فإن هذه الاتجاهات تحمل أهمية خاصة لاى طلبة الجامعة كونهم الثربحة التي تبنى Rليها توقعات المبتقبل ونقع على عاتقها مسؤوليات البناء والتنمية في اللقطاعات المختلفة الاقتطادية والاجنماعية. ومن هنا، فإن مشكلة البحث الحالي تمتزله في السؤال عن اتجاهات طلبة الجامعة نحو مفهوم المواطنة هل هي سلبية أم إيجابية؟ والسؤالث هل أتجاهات طلبة الجامعة نحو المواطنة تختلف باختلاف الجنس وباختلاف التخصص الدراسي لهم.

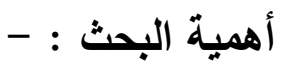

المواطنة واحدة من التحديات الرئيسة أمام الدول وأمام الأفراد الذين يمثلون مواطني هذه الدول. والتحدي يكمن في إعداد مواطن فعال في مجتمعه، ويعني حقوقه 
وواجباته، بحيث يكون مسؤولاً وملتزماً بمواطنته في بلده. وبعكس ذلك يكون الفرد مشتتاً بين انتماءات فرعية ربما تشكل الأولوية عنده في حال غياب مفهوم المواطنة أو ضعفه؛ إذ إن الدول المعاصرة، إضافة لتكونها من مؤسسات مختلفة ودساتير وقوانين، هي مشاريع اجتماعية متكاملة قائمة على التفاعل بين المواطنين الذين يمتلون مصدر السلطات.

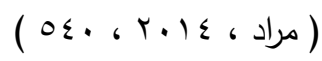

وفيما يتعلق بالمواطنة؛ فإن الدول المختلفة تسعى لتوجيه اهتمامها لنشر الوعي بين مواطنيها الذين يمنلون رأس المال الحقيقي في التتمية ونواحيها السياسية والثقافية والاقتصادية. والمواطنة تقوى في البلدان التي يكون فيها الفرد متمتعاً بحريته وبحرية اختياراته الفكرية والمادية. وقد يتأثز مفهوم المواطنة في المجتمعات التي تتطوي على اختلال كبير في مستويات المعيشة بين الأفراد. وتظهر أهمية مفهوم المواطنة في كونه يمنل الركيزة التي تقوم عليها المعرفة والاتجاهات الوطنية؛ إذ إن المواطنة تمثل الارتباط النفسي بين الإنسان وبلده ومواطني هذا البلد، والذين يشتركون معه باللغة والثقافة والظروف الاجتماعية والسياسية. وهذا الارتباط يمثل جوهر إخلاص الفرد والتزامه بالمسؤوليات والواجبات نحو وطنه.

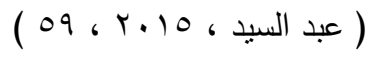

المواطنة واحدة من أهم القضايا التي تقع ضمن أبعاد التتمية بشكل عام. وإذا كانت المواطنة بمفهومها العريض تشير إلى الرابطة بين الفرد والدولة التي يعيش فيها كمواطن مرتبط بها ثقافيّاً وجغرافيّاً، فإن مفهوم المواطنة يعد من التوجهات الأساسية للمدنية والتي يؤشرها احترام القوانين والأنظمة العامة، واحترام الحريات الفردية، وحقوق الإنسان وقبول الآخرين والتسامح والحرية في التعبير وغير ذلك من المؤشرات عل قيم المواطنة الأساسية، وكيفما اختلفت الأطر الفكرية للمجنمعات.

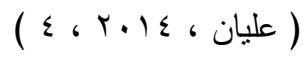


تعد المواطنة صفة للمواطن من خلالها تتضح حقوقه وواجباته. وهذه الصفة تتسم بالولاء للبلد ولوحدتها سواء في زمن الحرب أو السلام، وتظهر تلك الصفة من خلال التعاون مع المواطنين في سبيل تحقيق أهداف المجتمع. ويشير (الحبيب ، ه . . الى أن المواطنة تظهر في شعور الانسان بالروابط المشتركة مع الافراد في مجتمعه، وكذلك شعوره باستمرارية هذا المجتمع عبر الزمن، وايضّاً شعور الانسان بارتباطه بوطنه وانتمائه لمجتمعه وارتباط مستقبله بهذا المجتمع، وفي النهاية اندماج هذه المشاعر في مفهوم واحد يتمنل بالمواطنة التي تضم كل العلاقات بين الثخص ومجتمعه وهي تقوم على تحقيق الكفايات السياسية والاجتماعية.

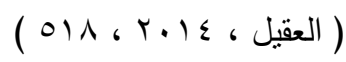

واذا كانت الاتجاهات تمثل استعدادّاً مكتسّباً نسبي الثبات يحدد مشاعر الفرد وبحدد سلوكه اتجاه مواضيع بعينها، وبحدد حكمه عليها بالقبول أو الرفض، فإن دراسة الاتجاهات تمكننا من فهم السلوك الآني؛ وكذللك التتبؤ بالسلوك المستقبلي

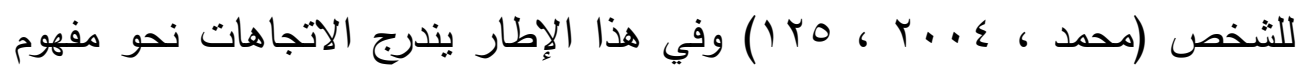
المواطنة؛ إذ إنها تمنت المحصلة لاستجابات الفرد نحو موضوعات منل التقيد بالواجبات نحو الدولة والمجتمع، ومعرفة الفرد لحقوقه وعدم تجاوزها وتبلور الاتجاهات نحو المواطنة أيضّاً من خلال تأييد أو رفض الحقوق والواجبات الخاصة في الفرد

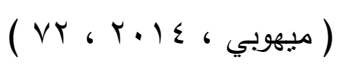
وفي كافة المجالات في المجتمع.

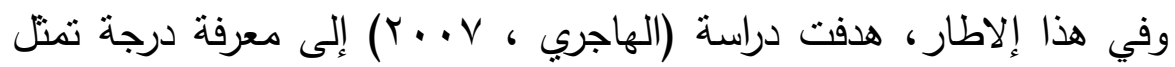
طلبة جامعة الكويت لقيم المواطنة ودور الجامعة في تتمية قيم المواطنة بين الطلاب. أجريت الدراسة على عينة من (VII) طالب من الذكور والإناث. وأظهرت نتائج الدراسة أن درجة طلاب جامعة الكويت على تمثل قيم المواطنة هي درجة مرتفعة. ولكل أبعادها. وهدفت دراسة (القحطاني ، . • (Y) للتعرف على مستوى قيم المواطنة

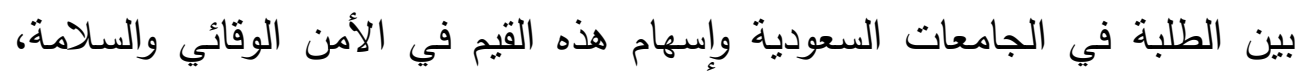
وكذلك الكثف عن المعوقات لقيم المواطنة، ومقومات ممارسة قيم المواطنة للطلبة. 
أجريت الدراسة على عينة مكونة من (ع^^) من الطلاب الذكور في عدة جامعات

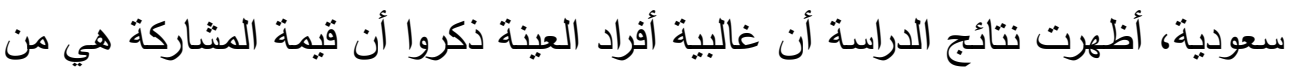
قيم المواطنة؛ ولكن أظهرت النتائج مستوى متدني في الجانب السلوكي، وأن غالبية أفراد العينة بتقيدون بالأنظمة والتعليمات خارج الوطن بصورة أفضل. وأظهرت النتائج

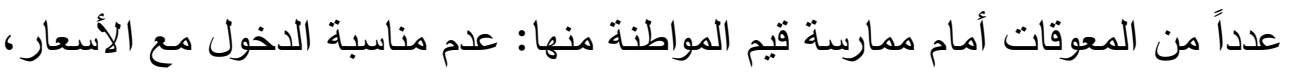

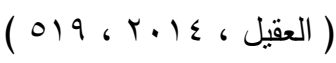
غلاء المعيشة، انتشار الواسطة، والبطالة. يتضح مما سبق أن البحث الحالي يستمد أهميته من أهمية المتغيرات التي يتتاولها ممثلة بالاتجاهات نحو مفهوم المواطنة؛ إذ تعبر هذه المتغيرات عن الطريقة التي يشعر بها الفرد ويسلك نحو مفهوم المواطنة والذي يعبر بدوره عن طريقة شعوره وسلوكه نحو مجتمعه ووطنه. كما يستمد البحث الحالي أهميته من أهمية الثريحة الاجتماعية التي يناولها، وهي طلبة الجامعة؛ إذ إن هذه الثريحة الاجتماعية تمثل

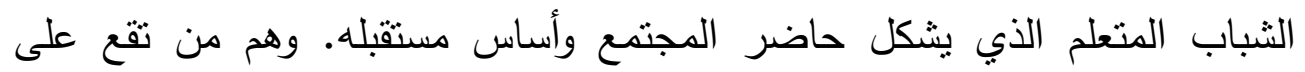
عاتقهم المهام المتعددة للتتمية الاجتماعية والاقتصادية والسياسية والتي تتطلب بدورها توجهاً ايجابيًاً نحو مفهوم المواطنة لينسنى إنجاز هذه المهام بشكل أمنل، يسهم في بناء دولة عصرية قائمة على مفاهيم المواطنة الحديثة.

\section{أهداف البحث :}

$$
\text { يهدف البحث الحالي إلى : }
$$

1 - بناء مقياس لقياس اتجاهات طلبة الجامعة نحو مفهوم المواطنة .

r - قياس اتجاهات طلبة الجامعة نحو مفهوم المواطنة .

r - التعرف على الفروق في اتجاهات طلبة الجامعة نحو مفهوم المواطنة وفق

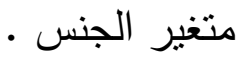

ع - التعرف على الفروق في اتجاهات طلبة الجامعة نحو مفهوم المواطنة وفق متغير التخصص الدراسي • - م 
ينحدد البحث الحالي بطلبة جامعتي بغداد والمستتصرية. وبالدراسات الأولية

$$
\text { تصديد المصطلحات : - - تحافة. ولكلا الجنسين ( ذكور - إناث ). }
$$

سيتم تحديد مصطلحات (الاتجاهات) (attitudes) و (مفهوم المواطنة)

: وكما يأني ( concept of citizenship)

اولاً - الاتجاهات (attitudes) :

( Allport, 1953 ) - تعريف

" الاتجاه حالة من الاستعداد العقلي والعصبي ينكون من خلال الخبرة ويؤثر تأثنرًاً

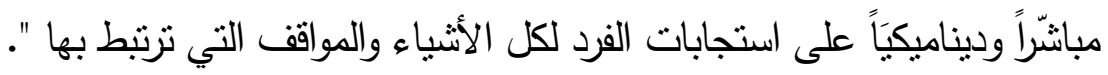

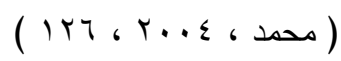

$$
\text { r - تعريف ( دافيدوف ، .91 191): - }
$$

مفاهيم متعلمة وتقويمية ترتبط بأفكارنا ومشاعرنا وسلوكنا.

( VVO ، 191. ، (دافيدوف )

\section{: Tesser \& Shaffer, 1990 ) ( تعريف}

" الاتجاه هو استجابة تقييمية إيجابية أو سلبية حول مثير ما، كأن يكون شخص،

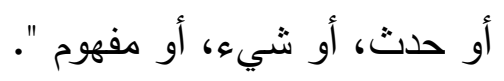

( Passer, 2001, 512 )

؛ - البحث الحالي يعرف الاتجاهات على أنها : -

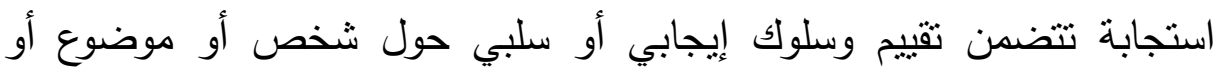

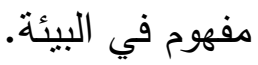


التعريف الاجرائي للاتجاهات :

هي الدرجة الكلية التي يحصل عليها المستجيب على الأداة المستخدمة لقياس الاتجاهات نحو المواطنة في البحث الحالي.

ثانياً : مفهوم المواطنة (concept of citizenship) : ( c)

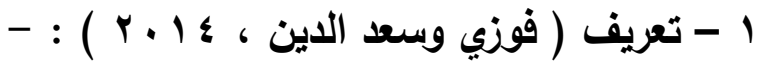

" علاقة والتزام له صبغة قانونية وسياسية وصبغة اجتماعية ونفسية، وهي صفة ينالها الفرد ليتمتع بالمشاركة الفعالة في المجتمع الذي يعيش فيه. وللمواطنة مكونات أساسية دنها، الانتماء، والواجبات، والحقوق، المشاركة الاجتماعية، القيم العامة ".

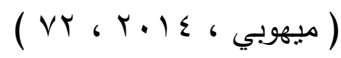

$$
\text { r - تعريف ( ضرغام ومهـي ، } 10 \text { ( } 10 \text { ) ) }
$$

" عبارة عن مشاعر الانتماء والولاء والتفاعل مع كل ما ينتمي إلى الوطن ".

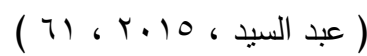

: Ramazan, 2017) - تعريف رابطة قانونية بين المواطن والدولة.

( Ramazan, 2017, 803 )

؛ - البحث الحالي يعرف مفهوم المواطنة بأنه :

علاقة الفرد بوطنه معبراً عنها بمشاعره وسلوكه اتجاه الوطن الذي يعيش فيه.

\section{التعريف الاجرائي للاتجاهات نحو مفهوم المواطنة :}

هي الدرجة الكلية التي يحصل عليها المستجيب على الأداة المستخدمة لقياس اتجاهات طلبة الجامعة نحو مفهوم المواطنة في البحث الحالي. 


\section{الفصل الثاني}

\section{الإطار النظري والدراسات السابقة}

تؤثز الاتجاهات في سلوك الفرد بشكل كبير، وتعمل على توجيه هذا السلوك وتحديده. ومن خلال اتجاهات الفرد يمكن التتبؤ بسلوكه في مختلف المواقف والظروف؛ إذ تؤدي الاتجاهات دورّاً مهماً في استجابة الفرد لمواقف الحياة المتغيرة وكيفية تعامله مع هذه المواقف.

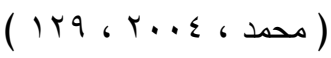

الاتجاهات هي تقييمات إيجابية، وسلبية، أو مختلطة لشيء ما، ويعبر عنها بمستوى معين من الثدة. كلمات مثل الحب، الود، الكراهية، الإعجاب هي امثلة على هي الكلمات التي يستخدمها الناس ليصفوا اتجاهاتهم. والاتجاهات لا يمكن تمثيلها على خط مستمر واحد يتراوح من الإيجابية المطلقة إلى السلبية المطلقة؛ إذ إن الاتجاهات

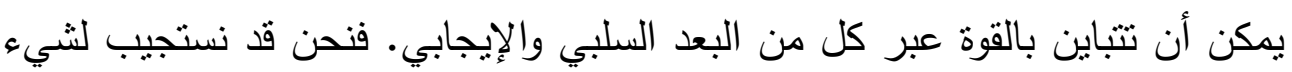
ما بانفعال إيجابي، وانفعال سلبي، وانفعال مزدوج (انفعالات قوية ولكن مختلطة)، أو بلامبالاة. وفي الحقيقة، يستطيع الناس أن يظهروا استجابات إيجابية وسلبية نحو نفس وله موضوع الاتجاه، بدون أن يشعروا بالتتاقض - ويحدث هذا عندما يكونون واعين بإحدى الاستجابات دون الأخرى. الاشخاص بصوغون تقييمات إيجابية وسلبية للناس، والأشياء، والأفكار التي يواجهونها، وهذه العملية هي في الواقع غالباً ما تكون تلقائية، منل الاستجابة المنعكسة.

( BREHM, 2002, 180 )

يدل مفهوم الاتجاه على توجهات الأفراد الفكرية، والاستعدادات العميقة

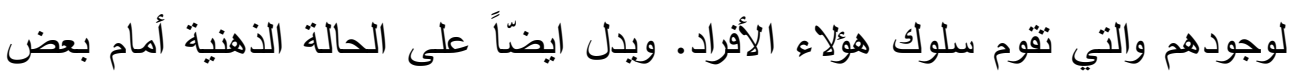


القيم. وترتبط هذه الاتجاهات بالثيء الذي تظهر نحوه بقر ارتباطها بدافعية الأفراد الخاصة. وفي دراسة الاتجاهات ثمة تميز بين الاتجاهات الثخصية التي يحملها الفرد نفسه (مثل تفضيلاته الجمالية)، وبين الاتجاهات الاجتماعية (منل الخيارات السياسية) تلك التي يكون لها انعكاس على الجماعات. والاتجاهات تمثل الفرد بكليته، ماضيه وحاضره، شخصيته وخبراته، بنيته النفسية الانفعالية والضغوط التي تسلطها عليه البيئة

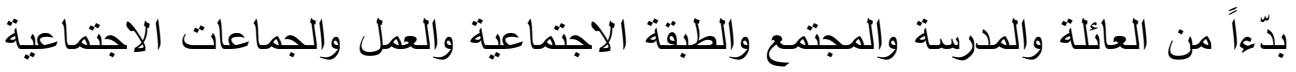
التي ينتسب بها. كل هذه الجهات تعمل على جعل اتجاهات الأفراد متجانسة، وهؤلاء الأفراد يميلون من جهته؛ لأن يمتتلوا بشكل تلقائي للمعايير السائدة في جماعاتهم. ويظهر ذلك في أنماط الأزياء، والأعراف السائدة والعادات الاجتماعية. وأيضّاً في المعتقدات والآراء؛ إذ إن الفرد يؤمن اندماجه الاجتماعي حين يتبنى المعايير السائدة في جماعته، في حين يصبح عرضه للنبذ من قبل الجماعة حين يرفض هذه المعايير • ولا توجد هناك اتجاهات معزولة بل مجموعات من الاتجاهات المنتظمة بمنظومات

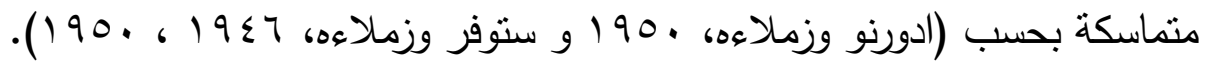

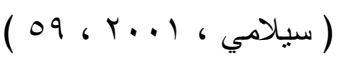

وإذا كان لكل فرد اتجاهاته نحو مواضيع متعددة ومختلفة، فإن من بينها اتجاهات

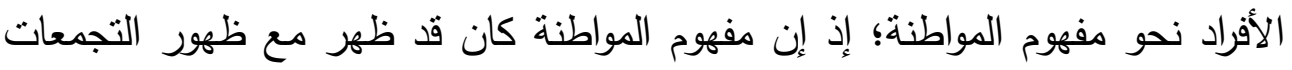
البشرية القائمة على تعاون الأفراد وفي الجماعة الواحدة، وذلك لغرض نجاح الجماعة في

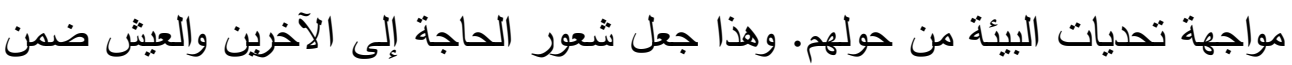
جماعة ينتسب لها، يظهر لدى الفرد أو لدى المواطن. ومن ثم أخذ مفهوم المواطنة بالتطور ضمن المجتمعات عبر مراحل متعاقبة من تاريخه حدثت فيها في الوقت نفسه تحولات في أنظمة الحكم في تلك المراحل. بحيث كانت المواطنة في فترات أنظمة الحكم التقليدية مقتصره على فئات معينة، ومن ثم أصبحت المواطنة في ظل الأنظمة الديمقراطية تتحدد بالحقوق والواجبات، وتحقيق العدالة بين الأفراد في المجتمع. ( ) ( $1 \leq 9 ، r .1 V ،$ 
تعد المواطنة النطاق الأوسع الذي يضم الانتماءات الاجتماعية المتباينة

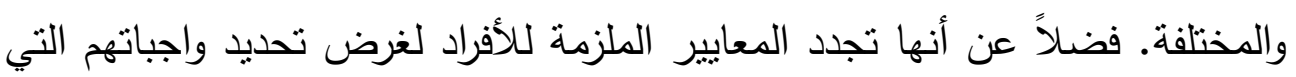
تسعى في النهاية لتحقيق الاندماج والتعاون من أجل توفير حقوق الأفراد من ناحية، ومن ناحية أخرى تعمل المواطنة على تكريس المسؤولية العامة والأهداف المشتركة.

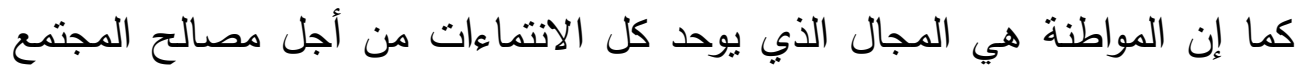
ضمن أطر نظامية وعلى أساس موحد من المصلحة العامة.

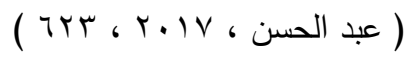

يرتكز المعنى الاجتماعي الحديث لمفهوم المواطنة من حيث الجوهر على

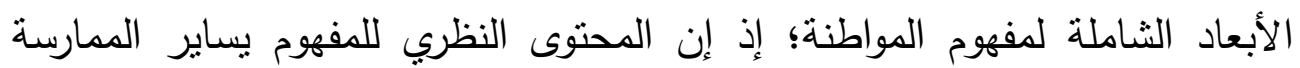

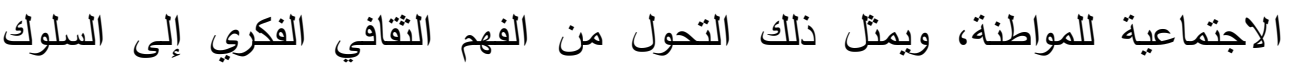
الاجتماعي الفاعل القائم على الاندماج وعلى التشارك. وبهذا المعنى فإن المواطنة هي امتلاك الحقوق الاجتماعية والسياسية والددنية والاقتصادية في مقابل الالتزام بواجبات متعددة في إطار الوطن الذي ينتمي إليه الفرد. وبهذا تمثل المواطنة التزامًاً

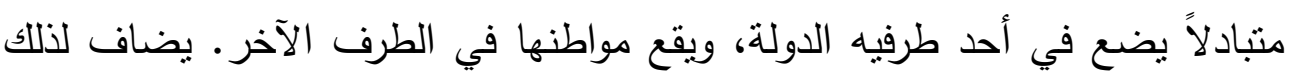

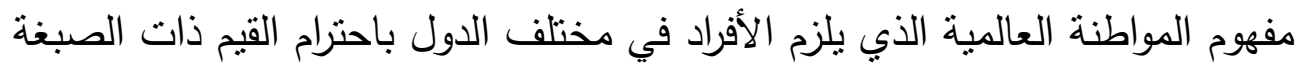

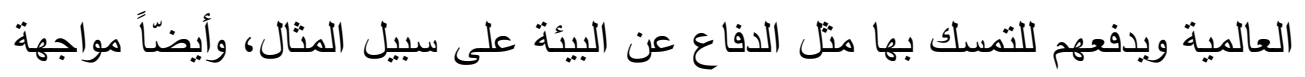

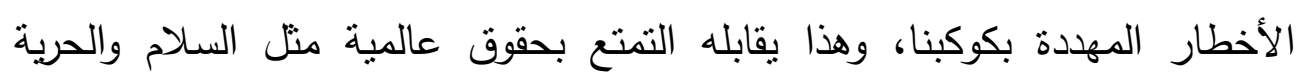

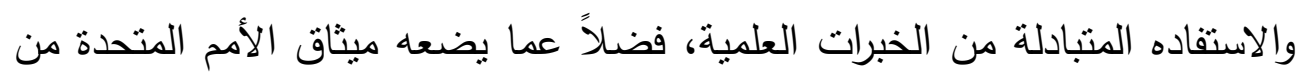
التزامات تتزتب على هذه الهيئة الدولية نحو كل فرد في العالم.

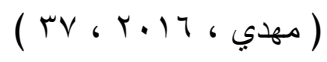

طبقاً لـ (Bellamy, 2013) هناك نوعان من النظريات النتي نتتاول المواطنة: النظريات المعيارية (normative): وهي النظريات الني تحاول تحديد حقوق الفرد وواجباته. والنوع الآخر هي النظريات التجريية (empirical): والتي 
تهدف إلى وصف وتفسير الكيفية التي تمكن الفرد من حيازة تلك الحقوق والواجبات. نوع النظريات المعيارية الخاصة بالمواطنة هي النظريات السائدة لتفسير المواطنة وهي نظريات متجذرة في اليونان وروما القديمتين. في حين أن النظريات التجريبية تأخذ بالاعتبار تطور المواطنة الديمقراطية ضمن الدول القومية لأوربا الغربية. يهذف هذان النمطان من نظريات المواطنة لرؤية دول ديمقراطية ودول ذات رفاهية بوصف تلأك النظريات هي مظاهر جزئية واندماج لجوانب مختلفة متعددة من النماذج النظرية المعيارية السائدة لتفسير المواطنة.

( Bellamy, 2013, p27 )

وبناءً على ما سبق، فإن المواطن هو عضو في الأمة، كما يراه (BÜYÜK, 1986) وسياسية وله حق الاقتراع في الدولة (خلافّاً للأجنبي). وطبقاً لـ (Harvey, 1997) في (Ramazan,2017, 802)، فإن المواطن هو شخص يعيش في الدولة، ويحميه القانون، وله حق التصويت في الانتخابات، ويستطيع فهم المسؤوليات المترتبة عليه كمواطن يحميه ذلك القانون، ويدفع الضرائب ويقر بحقوق الآخرين. طبقا لـ (Ramazan,2017, 802) في (Raral,2000) فإن المواطنين هم جميع الناس الذين يعيشون في نفس البلد الأم ويرتبطون بنفس الدولة وبنفس رابط المواطنة. والدولة تحدد من هو المواطن بالقانون.

( Ramazan,2017, 802 )

\section{المواطنة :}

تُعرف المواطنة اليوم بشكل مختلف في البلدان المختلفة طبقاً للأوضاع الاجتماعية، والثقافية، والاقتصادية، ووضع الجغرافية السياسية لتلك البلدان. وفي الوقت الذي أصبح فيه العالم قرية عالمية، فإنه من المحتوم أن تكون لتلاك التعريفات بعض النقاط المرجعية المشتركة. وفي الوقت الذي يعرف في(Blasubramanian) في (Rozemeüer,2001, 16) المواطنة بأنها قابلية الفرد على المشاركة في تقدم 
وتطور المجتمع. فإن (monoye) في (Rozemeüer,2001, 16) يعرفها على أنها علاقات بين الناس والدولة. لذا فهي عملية تتألف من واجبات ومسؤوليات متبادلة بين الدولة والفرد. وطبيعة هذه العملية تتحدد بواسطة الميزات الثقافية والحياتية والاقتصادية ومميزات البنية السياسية والجغرافية السياسية لكل الدول. وهذه المميزات المحدة؛ وبسبب التغيرات السريعة الأخيرة والعلاقات الاجتماعية، يبدو أنها تتحول

( Ramazan,2017, 803 )

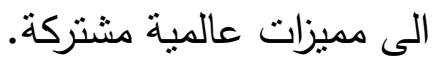

والبحث الحالي يتبنى المدخل النظري الوارد في دراسة (Ramazan,2017) في أن المواطنة هي عملية تتألف من الواجبات والمسؤوليات المتبادلة بين الدولة والفرد تتثكل حسب المميزات الاجتماعية، والثقافية والاقتصادية وأسلوب الحياة والتزكيبة السياسية في البلد.

وفي سياق دراسات الاتجاه نحو المواطنة جاءت دراسة (فوزي، سعد الدين،

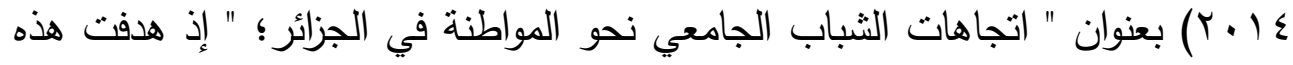
الدراسة إلى قياس اتجاهات الثباب الجامعي نحو المواطنة فيما يخص الواجبات والحقوق بهدف الحفاظ على الاستقرار الاجتماعي والهوية الوطنية. ولغرض تحقيق أهداف الدراسة

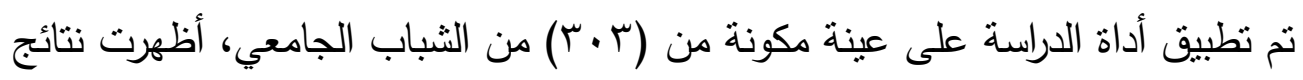

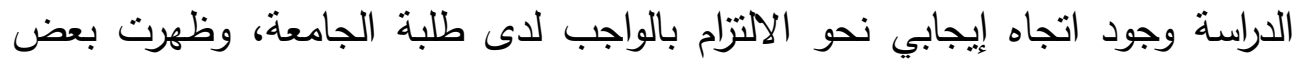
الاتجاهات السلبية نحو الحصول على الحقوق، كالدق في الدساواة والحق في العمل

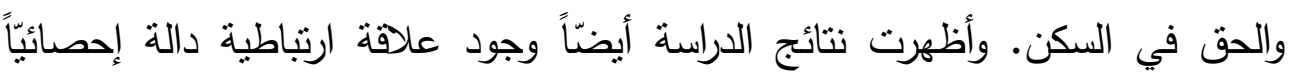
وموجبه بين الاتجاه نحو الواجبات والاتجاه نحو الحقوق لدى طلبة الجامعة.

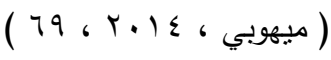

جاءت دراسة (Özbck and Susam, 2017) بعنوان" تقييم اتجاهات المعلمين المستقبليين نحو المواطنة وتعليم المواطنة؛" وتهدف هذه الدراسة التي أجريت 
في نركيا إلى التعرف على اتجاهات المعلمين المستقبليين الذين يدرسون تعليم الإعداد التربوي، نحو المواطنة وتعليم المواطنة بحسب جنسه وتخصصهم، وانتمائهم العرقي والمنطقة الجغرافية التي يسكنون فيها. وتهدف الدراسة ايضاً لتوضيح المضامين الثاملة لمفهوم المواطنة، وتعليم المواطنة. ولتحقيق أهداف الدراسة تم تبني استبيان لقياس

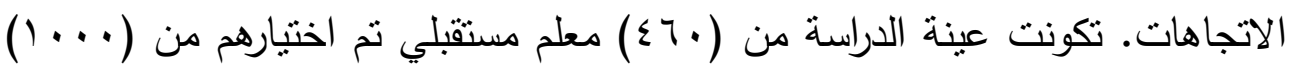

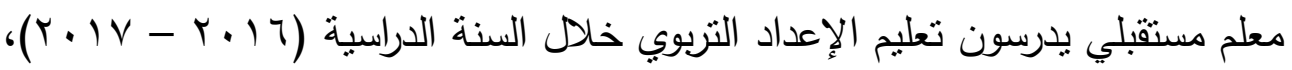
ونم استخدام طريقة تضمن أعلى تباين في العينة. ولغرض جمع البيانات تم استخدام مقياس الاتجاه الوطني ومقياس تعليم الوطنية. يتضمن مقياس الاتجاه الوطني " المواطنة العمياء " و " المواطنة البناءه ". في حين يتضمن مقياس تعليم الوطنية بعدّاً

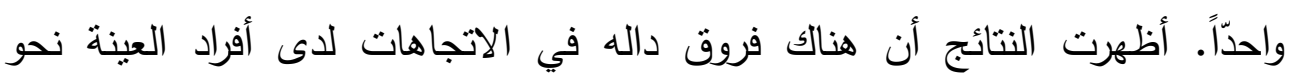
المواطنة وتعليم المواطنة على وفق تخصصهم وانتمائهم العرقي، وليس هناك فروق في اتجاهاتهم على وفق جنسهم وموقعهم الجغرافي. ويستتتج من هذا أن متغير الجنس وفي ولن والمنطقة الجغرافية ليس لهما دور كبير في تكوين اتجاهات المعلمين المستقبليين نحو المواطنة (سواء المواطنة العمياء أو المواطنة البناءة)، ولا نحو تعليم المواطنة. في حين

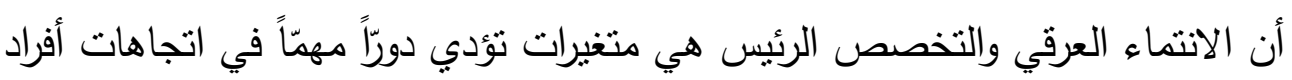

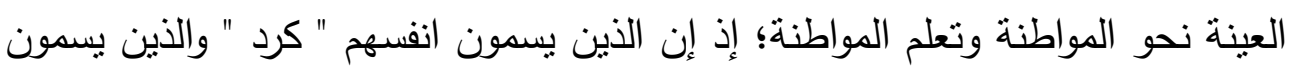

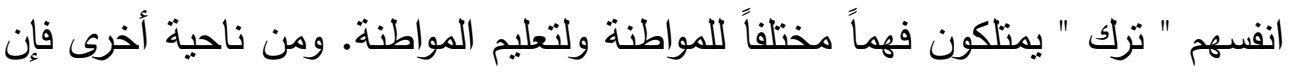
المشتركين في برنامج الإعداد التربوي لأقسام العلوم الطبيعية والمشتركين في برنامج الأقسام الإنسانية لديهم فهمّاً مختلفّاً للمواطنة ولتعليم المواطنة.

( Ramazan,2017, 801 )

وهدفت دراسة (هلا ، . . . ب) إلى معرفة وجود مظاهر المواطنة لدى طلاب المرحلة الثانوية حسب وجهة نظر أولياء الأمور والمدرسين، وكذلك الطلبة أنفسه في دولة الكوبت. وأثنارت النتائج أن الهيئة التدربسية كانت موافقة بدرجة 
متوسطة على وجود مظاهر المواطنة عند الطلاب في المرحلة الثانوية. في الوقت الذي وافق أولياء الأمور، والطلاب بدرجة متوسطة على ذلك. واقترحت النتائج أن الوسائل المتلى لتتمية المواطنة هي المناهج المدرسية والصحافة والإعلام. والجهات الأكثر إسهامًاً في تتمية المواطنة هي الأسرة والأصدقاء والمدرسة.

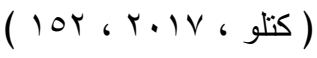

كما هدفت دراسة (الثويحات ، ؟ . بץ) إلى التعرف على درجة تمنل الطلاب في الجامعات الأردنية لمفاهيم المواطنة الصالحة. وتأثز هذه المفاهيم بمتغيرات مستوى تعليم والدي التلميذ وجنسه ونوع مدرسته التي كان قد تخرج منها والبيئة التي يسكن فيها، ومستواه التحصيلي، ونوع جامعته، وتخصصه الدراسي.

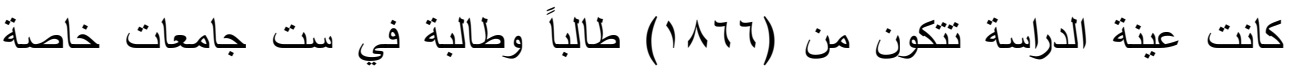
ورسمية. النتائج أشنارت إلى أن النسبة الكلية لتمثل طلبة الجامعة لمفاهيم المواطنة هي (r7\%) وهذه النسبة عدت بأنها دون المستوى الأمثل للتمنل الإيجابي الذي اعنبر بإنه (VV) فأكثر. كما أنثارت النتائج أن هناك فروقاً داله في درجة تمنل طلبة الجامعة لمفاهيم المواطنة، وذللك على وفق كل المتغيرات ولصالح الطلاب الذكور والطلاب الذين يمتاز آباؤهم بمستوى أعلى من التعليم والطلاب من أبناء المدن، والطلبة المتخرجين من مدارس خاصة، والطلاب ممن هم من غير تخصصات العلوم الإنسانية. وأشارت النتائج أن الفروق في درجة تمثل مفاهيم المواطنة لدى الطلاب مابن هي لصالح الطلاب في السنة الثانية ولصالح طلاب الجامعات الخاصة. ( عليان ، ع . ، ، . (1)

أما دراسة (الجبوري ، ^ . . ץ)؛ فقد كان هدفها قياس مفهوم المواطنة لدى طلبة الجامعة، وهي دراسة ميدانية أجربت على طلاب جامعة بابل، الهدف منها التعرف على طبيعة مفهوم المواطنة لديهم، وكذلك معرفة الفروق بين الطلبة فيما يتعلق بالمواطنة على وفق متغيرات الجنس، والمستوى التعليمي للوالدين والمستوى 
الاقتصادي، والخلفية الاجتماعية. أثنارت نتائج الدراسة أن (ع , 0ء ٪) من أفراد العينة

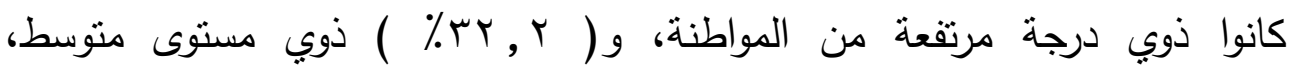

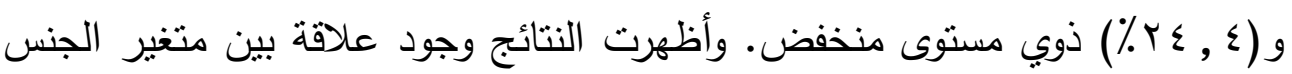
ومفهوم المواطنة؛ إذ إن أفراد العينة من الإناث كن أعلى مواطنة من الذكور، وأن وان

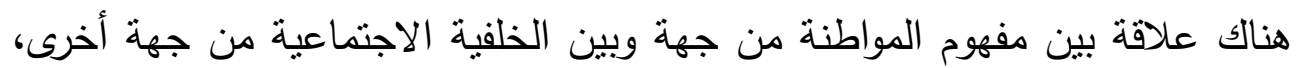
فذوي الخلفية الحضرية أعلى مواطنة من غيرهم. وأظهرت النتائج أن الطلبة من من من الطبقة الوسطى أعلى مواطنة من غيرهم. ولم تظهر النتائج علاقة بين مفهوم المواطنة والمستوى التعليمي للوالدين.

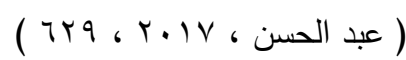




\section{الفصل الثالث}

\section{إجراءات البحث}

$$
\text { أولاً : - مجتمع البحث : - }
$$

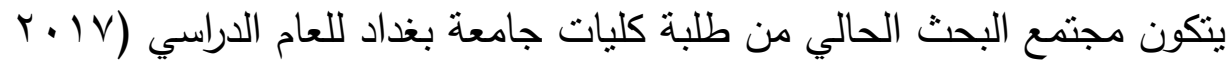

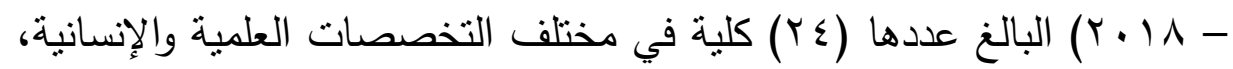
موزعة الى (Y) (Y) كلية تمنل التخصصات الإنسانية و (Y) (Y) كلية تمنل التخصصات العلمية.

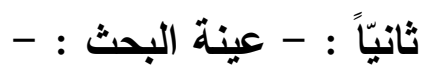

أجري البحث الحالي على عينتين من طلبة جامعة بغداد وكما يلي : 1 - عينة بناء المقياس : وهي عينة مكونة من ( (. ب) طالب وطالبة من كليات الصيدلة والعلوم والتخصصان تمثنان التخصصات العلمية. وكليات الآداب والتربية (ابن رشد) تمثنان التخصصات الإنسانية. تم اختيار أفراد العينة بشكل عشوائي موزعين بواقع (·ه) طالباً وطالبة من كل كلية. وموزعين حسب الجنس إلى (Yo) طالباً و (Yo) طالبة. تم اختيار هذه العينة للتعرف على ثبات المقياس المستخدم في البحث الحالي، والتعرف على القوة التمبيزية لفقرات المقياس. r - عينة التطبيق النهائي : - وهي عينة مكونة من ( . . (Y) طالب وطالبة أخذت من كليات الهندة وطب الأسنان، تمثلان التخصص العلمي وكليتي اللغات والإدارة والاقتصاد في جامعة بغداد والتي تمثنلان التخصص التص الإنساني. تم اختيار أفراد العينة بشكل عشوائي بواقع (••) طالباً وطالبة 
لكل كلية من الكليات المذكورة، موزعين حسب الجنس إلى (Y0) طالباً و(Y0) طالبة. وقد تم تطبيق المقياس المستخدم في البحث الحالي على هذه العينة بعد أن اكتمل بناؤه، وذلك لتحقيق أهداف البحث الحالي.

$$
\text { ثالثاً : - أداة البحث : - - }
$$

لغرض قياس اتجاهات طلبة الجامعة نحو مفهوم المواطنة، قام الباحث بيناء مقياس يتكون من ( •ع) فقرة وفقاً لطريقة (ليكرت) وفيما يلي وصف للإجراءات التي مر بها بناء المقياس. ا 1

تم جمع فقرات المقياس من أكثر من مصدر وكما يلي : أ- أخذت بعض الفقرات من الدراسات السابقة التي استخدمت مقاييس مشابهة لمقياس البحث الحالي؛ إذ جرت إعادة صياغة لهذه الفقرات لكي تلائم أهداف البحث الحالي وتلائم مجتمعه. ب- استبيان استطلاعي (ملحق () تم تطبيقه على عينة عشوائية تكونت من من اهن

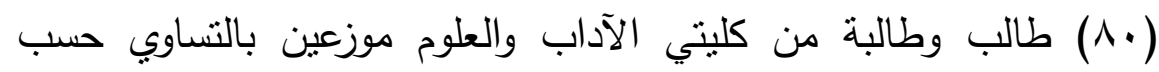
الجنس والتخصص بواقع (• †) طالباً و (·r) طالبة لكل كلية.

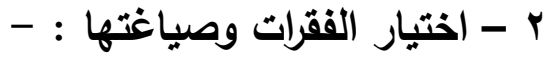

تمت صياغة (• ع) فقرة بالاستتاد إلى مصادر الفقرات المذكورة آنفاً. وراعى الباحث انسجام الفقرات مع متغير البحث وكذلك انسجامها مع مجتمع البحث

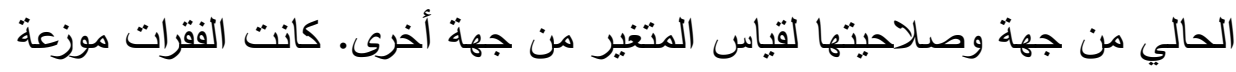
إلى فقرات إيجابية وفقرات سلبية؛ إذ تعكس الفقرات الإيجابية اتجاهّاً ايجابيّاً نحو 
مفهوم المواطنة. في حين أن الفقرات السلبية تعكس اتجاهِّاً سلبيّاً نحو مفهوم المواطنة.

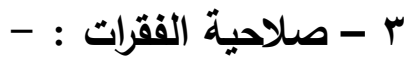

قام الباحث بعرض الفقرات التي تم جمعها في الخطوات السابقة على مجموعة من الخبراء (ملحق r)، وذلك بهدف التحقق من صلاحيتها ومن صدقها كونها تقيس المتغير الذي وضعت لقياسه. وقد اعتمدت نسبة اتفاق (. ( . ) فأكثر بين الخبراء معياراً لإبقاء الفقره في المقياس. بعد الاطلاع على الآراء المقدمة من قبل مجموعة الخبراء على كل فقرة في المقياس، ظهر أن الفقرات لإهاء جميعها كانت قد حازت نسبة الاتفاق الكافية لإبقائها في المقياس.

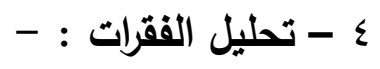

استخدم الباحث طريقة علاقة الفقرة بالمجموع الكلي للمقياس لغرض تحليل فقرات المقياس؛ إذ تم في هذا الإجراء استخراج العلاقة الارنباطية بين درجات كل فقرة من فقرات المقياس وبين الدرجة الكلية للمقياس باستخدام معامل ارتباط بيرسون. ويشير الارتباط المرتقع إلى قوة علاقة كل فقرة بالمقياس ككل. ولقد ظهر أن كل الفقرات كان تمتاز بعلاقة قوية بدرجة المقياس الكلية؛ إذ كانت كل

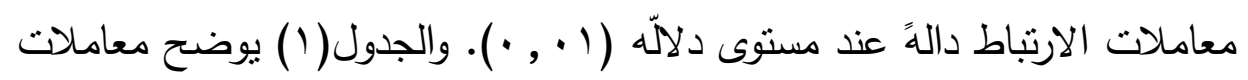
ارتباط فقرات مقياس الاتجاهات نحو مفهوم المواطنة بدرجة المقياس الكلية. 
جدول (1)

معاملات ارتباط فقرات مقياس اتجاهات طلبة الجامعة

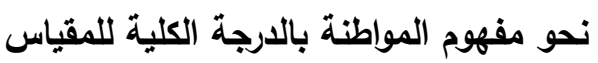

\begin{tabular}{|c|c|c|c|}
\hline معامل الارتباط & $ت$ & معامل الارتباط & $ت$ \\
\hline$\cdot, r \wedge$ & YI & ד & 1 \\
\hline., 01 & rr & $\cdot, r \wedge$ & r \\
\hline$\cdot, r q$ & rr & $\cdot, r v$ & $r$ \\
\hline$\cdot, r$. & $r \varepsilon$ & - , rq & $\varepsilon$ \\
\hline$\cdot, r q$ & ro & $\cdot, 0 \wedge$ & 0 \\
\hline$\cdot, \mu_{1}$ & Y & $\cdot$, , 1 & 7 \\
\hline$\cdot, I V$ & rV & $\cdot, \mathrm{r} \wedge$ & v \\
\hline$\cdot, 19$ & $r \wedge$ & • , t & $\wedge$ \\
\hline$\cdot, r_{0}$ & rq & $\cdot, \leq V$ & 9 \\
\hline$\cdot, r v$ & r. & , , \{ & 1. \\
\hline • , & r & $\cdot, r \leqslant$ & 11 \\
\hline & rr & ., or & ir \\
\hline$\cdot, r V$ & $r r$ & & ir \\
\hline - r, ro & ๘ & $\cdot, 19$ & $1 \varepsilon$ \\
\hline$\cdot, \leqslant \wedge$ & ro & • & 10 \\
\hline$\cdot, r \wedge$ & Ty & $\cdot, r r$ & 17 \\
\hline$\cdot, \leqslant r$ & rv & $\cdot, \uparrow \wedge$ & IV \\
\hline$\cdot, 0$. & $r \wedge$ & $\cdot, r r$ & 11 \\
\hline$\cdot, Y_{1}$ & $r q$ & $\cdot, \leq Y$ & 19 \\
\hline • , & $\varepsilon$. & $\cdot, \pi r$ & $r$. \\
\hline
\end{tabular}




\section{ه - صدق المقياس :}

اعتمد الباحث الصدق الظاهري بوصفه مؤشّرًا على صدق المقياس، وذلك من خلال عرض الفقرات على مجموعة الخبراء الذين اتفقت آراؤهم على صلاحية

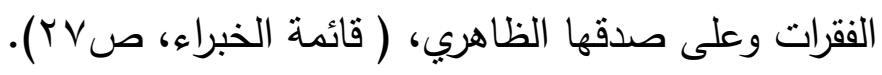
7 -

اعتمد الباحث طريقة الاتساق الداخلي عن طريق التجزئة النصفية لغرض التحقق من ثبات المقياس المستخدم في البحث الحالي. فقد تم اختيار ( . . ( ) استمارة بشكل عشوائي من استمارات عينة البناء البالغ عددها ( . . ب) طالب وطالبة. كانت الاستمارات موزعة بالتساوي طبقاً للجنس وللتخصص الدراسي. قسمت الفقرات في المقياس إلى نصفين طبقاً لتسلسلاتها الفردية والزوجية في صورة المقياس الأولية. تم حساب معامل الارتباط بين نصفي المقياس باستخدام معامل ارتباط بيرسون، وقد بلغ ( V9 , • ). ومن ثم طبقت معادلة سبيرمان - براون لتصحيح معامل الارتباط، فبلغ معامل الثبات (عی , •). وهو ثبات جيد إذا ما قورن بثبات المقاييس المماثلة في

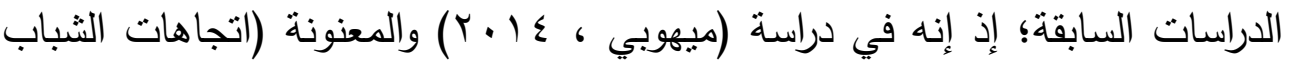
الجامعي نحو المواطنة في الجزائر)، كان ثبات المقياس ككل والمستخدم في هذه الدراسة هو (·) , · ).

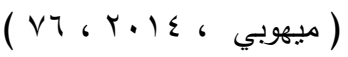

وهكذا أصبح مقياس اتجاهات الطلبة نحو مفهوم المواطنة مكتملاً بصورته النهائية المكونة من (• ع) فقرة (ملحق r). تتم الإجابة على الفقرات بواسطة متدرج من خمسة بدائل. وقد أعطيت للبدائل الخمسة درجات نتراوح بين (1 - 0). فإذا كانت الفقرة إيجابية، تكون البدائل ودرجاتها كما يلي، (موافق جداً) درجته (0)، (موافق) درجته (ع)، (متردد) درجته (ץ)، (غير موافق) درجته (Y)، (غير موافق 


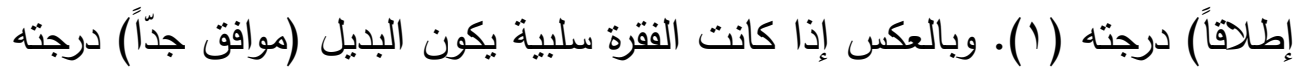

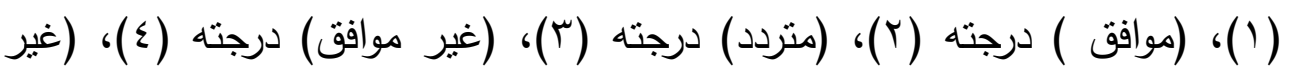

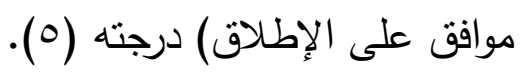

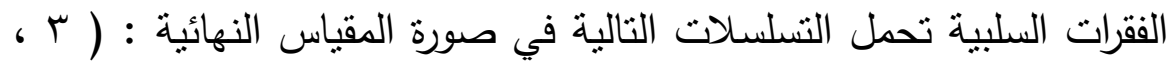

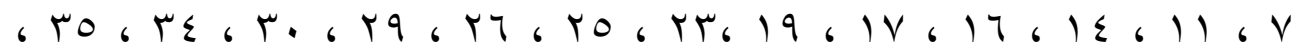

رابعًاً : - الوسائل الإحصائية :

استخدمت في البحث الحالي الوسائل الإحصائية التالية : -

1 - معامل ارتباط بيرسون لمعرفة علاقة الفقرة بدرجة المقياس الكلية، ومعرفة العلاقة بين نصفي المقياس لمعرفة ثبات المقياس.

r - معادلة سبيرمان براون لتصحيح معامل الارتباط بين نصفي المقياس لمعرفة

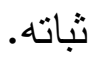

r - الاختبار الثائي لعينة واحدة لقياس اتجاهات طلبة الجامعة نحو مفهوم

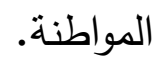
ع - الاختبار التائي لعينتين مستقلتين لقياس الفروق في اتجاهات طلبة الجامعة نحو مفهوم المواطنة حسب متغيري الجنس والتخصص الدراسي. 


\section{الفصل الرابع}

نتائج البحث :

سيتم في هذا الفصل عرض نتائج البحث الحالي طبقاً لأهدافه، وستتم مناقتة وتقسير هذه النتائج. وكذلك تقديم بعض التوصيات والمقترحات بناءً على نتائج البحث.

الهدف الأول : بناء مقياس لاتجاهات طلبة الجامعة نحو مفهوم المواطنة. لقد ثم تحقيق هذا الهدف عن طريق إجراءات بناء المقياس في الفصل الثالث من البحث الحالي، واكتمل بناء المقياس بصورته النهائية المتكونة من (•ـ) فقرة، ملحق (r).

الهرف الثاني : قياس اتجاهات طلبة الجامعة نحو مفهوم المواطنة. أظهرت نتائج البحث الحالي أن الوسط الحسابي لدرجات عينة التطبيق

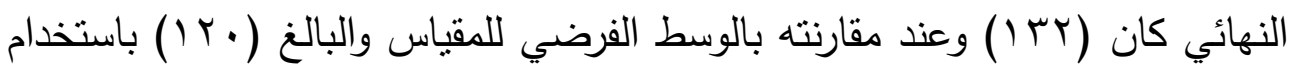

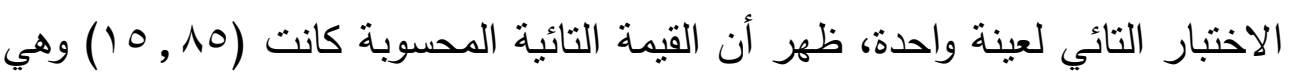
دالةَ عند مستوى ( 0 . , • ) عند مقارنتها بالقيمة التائية الجدولية البالغة (79 9 , ( ) مما يشير إلى أن طلبة الجامعة لديهم اتجاهات إيجابية نحو مفهوم المواطنة. والجدول(r) يوضح ذللك.

جدول (ץ) الاختبار التائي لعينة واحدة لمعرفة دلالة الفروق بين الوسط الحسابي والوسط الفرضي لعينة البحث على مقياس اتجاهات طلبة الجامعة نحو مفهوم المواطنة

\begin{tabular}{|c|c|c|c|c|c|c|}
\hline مستوى & الجائية القيمة & التائية القيمة & الانعراف & الفرضي & الوسابي & عدد الفراد \\
\hline$\cdot, .0$ & 1,97 & 10,10 & $7, r$ & ir. & Irr & $r \ldots$ \\
\hline
\end{tabular}


تتسق هذه النتيجة مع نتائج دراسة (الهاجري ، V . . Y) التي وجدت أن درجة

طلاب جامعة الكويت على تمثل قيم المواطنة هي درجة مرتفعة، (العقيل ، ع ا • ب ،

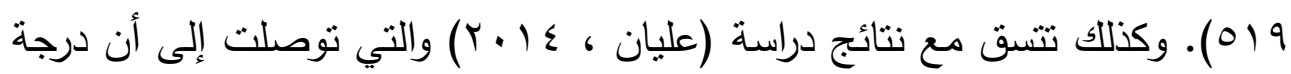
تمنل طلبة جامعة الأقصى لقيم المواطنة كانت مرتفعة، (عليان ، ع ( ب ، ، ()). وكذلك تتسق مع نتائج دراسة (عبد الحسين ، V V. V) التي أجريت على عينة من طلبة الجامعة المستصرية والتي توصلت إلى أن طلبة الجامعة لديهم شعور بالحرص

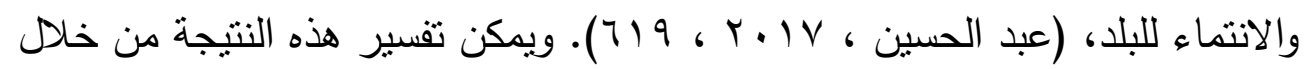
الإطار النظري لـ (Ramazan,2017)؛ إذ إن طلبة الجامعة يحملون اتجاهات إيجابية نحو عملية المواطنة التي تتألف من الواجبات والمسؤوليات المتبادلة بينهم وبين الدولة. وقد تشكلت هذه الاتجاهات الإيجابية طبقاً للمميزات الاجتماعية والثقافية التي تميز طلبة الجامعة ضمن المجتمع العراقي من إدراك لمفهوم المواطنة وأهميته في بناء وتتمية البلد والذي يؤهلهم لاكتساب تلك الاتجاهات الإيجابية.

الهدف الثالث : التعرف على الفروق في اتجاهات طلبة الجامعة نحو مفهوم المواطنة على وفق متغير الجنس.

أظهرث نتائج البحث الحالي أن الأوسط الحسابي لعينة الذكور كان (سM ()

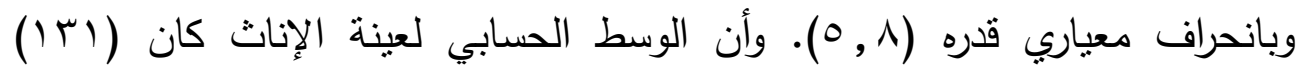
وبانحراف معياري قدره (0 , 7). وباستخدام الاختبار التائي لعينتين مستقلتين، ظهر أن القيمة التائية المحسوبة كانت (اسهاه , •) وهي أدنى من القيمة التائية الجدولية البالغة (79 , ( ) عند مستوى دلاله (0. . . ).) ونتير هذه النتيجة الى عدم وجود فروق ذات دلاله في اتجاهات طلبة الجامعة نحو مفهوم المواطنة على وفق متغير الجنس. والجدول (ب) يوضح ذلك. 


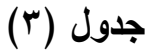

الاختبار التائي لعينتي الذكور والإناث لمعرفة الفروق في اتجاهات طلبة الجامعة نحو مفهوم المواطنة على وفق متغير الجنس

\begin{tabular}{|c|c|c|c|c|c|c|c|}
\hline الدلالة & القيمة التائية & القيمة التائية & الانحراف & الوسابي & العدد & العينة & 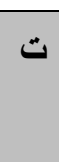 \\
\hline \multirow{2}{*}{$\cdot,}$. & \multirow{2}{*}{1,97} & \multirow{2}{*}{ I, , } & $0, \wedge$ & Irr & $1 \ldots$ & ذكور & 1 \\
\hline & & & 1,0 & $|r|$ & $1 \ldots$ & اناث & $r$ \\
\hline
\end{tabular}

تتفق هذه النتيجة مع نتائج دراسة (Özbek and Susam, 2017) التي أثنارت إلى عدم وجود فروق دالهَ في اتجاهات أفراد عينة الدراسة نحو المواطنة على

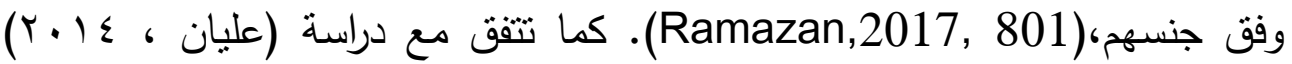
التي كان من بين نتائجها عدم وجود فروق ذات دلالةَ إحصائية في درجة تمثل طلبة جامعة الاقصى لقيم المواطنة تعزى لمتغير الجنس، (عليان ، ع ( ب r ، ()). إلا إن هذه النتيجة لا تتفق مع ما توصل إليه دراسة (الجبوري ، 1 . . r) التي هدفت لقياس مفهوم المواطنة لدى طلبة جامعة بابل، والتي اظهرت نتائجها وجود علاقة بين مفهوم

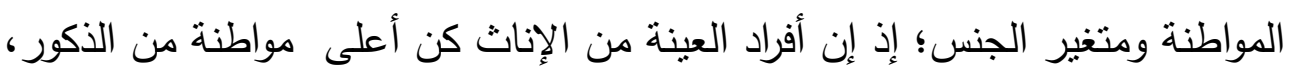

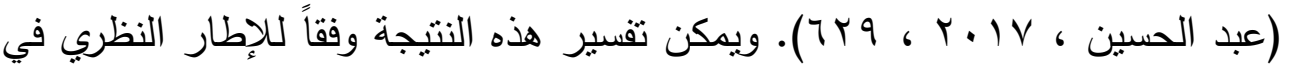
البحث الحالي والمستمد من (Ramazan,2017)، حيث إن هذه النتيجة تقيد أن طلبة الجامعة من كلا الجنسين (الذكور والاناث) ينتمون لمجتمع ينتابه أفراده عموماً في المميزات الاجتماعية والثقافية وأسلوب الحياة مما يجعلهم يحملون اتجاهات مثقاربة لمفهوم المواطنة. الذي يمنل رؤيتهم المنسجمة للعملية المتكونة من الحقوق والواجبات والمسؤوليات المتبادلة بينهم وبين الدولة. والتي تشكل لديهم مفهوم المواطنة. 
الهاف الرابع : التعرف على الفروق في اتجاهات طلبة الجامعة نحو مفهوم المواطنة على وفق متغير التخصص الدراسي.

أظهرت نتائج البحث الحالي أن الوسط الحسابي لعينة التخصص العلمي كان

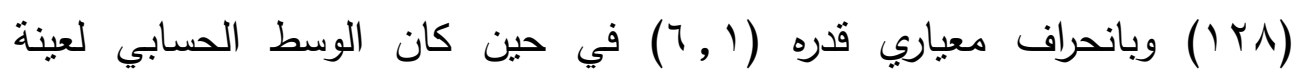

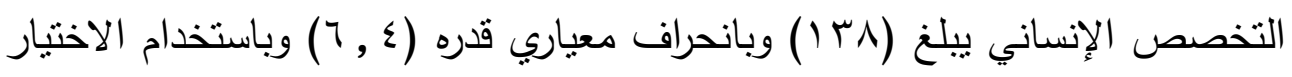

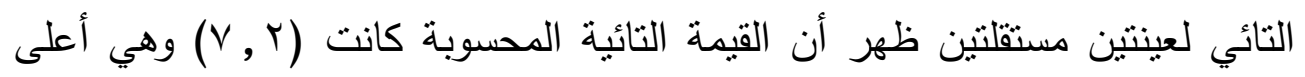
من القيمة التائية الجدولية البالغة (79 , ( ) عند مستوى دلالةَ (0. . . •). وتتشير هذه النتيجة إلى وجود فروق ذات دلاله إحصائية في اتجاهات طلبة الجامعة نحو مفهوم المواطنة على وفق متغير التخصص الدراسي؛ أي إن الطلبة من ذوي التخصص إنهان

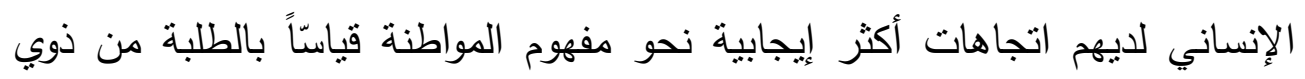
التخصص العلمي. والجدول (ع) يوضح ذلك.

\section{جدول (๕)}

الاختبار التائي لعينتي التخصص العلمي والإنساني لمعرفة الفروق على وفق متغير التخصص الدراسي

\begin{tabular}{|c|c|c|c|c|c|c|c|}
\hline مستوى & القيمة التائية & القيمة التائبة & الانحراف & الحسابي & العدد & العينـة & $ت$ \\
\hline \multirow{2}{*}{$\cdot, 0$} & \multirow{2}{*}{1,99} & \multirow{2}{*}{$v, r$} & צ & 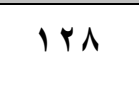 & $1 \ldots$ & إنساني & 1 \\
\hline & & & 7,1 & 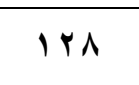 & $1 \ldots$ & علمي & $r$ \\
\hline
\end{tabular}

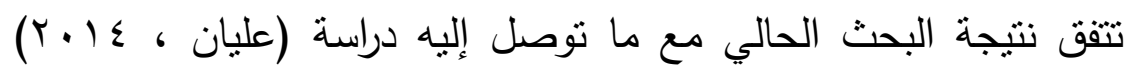
التي أظهرت نتائجها وجود فروق ذات دلالةَ إحصائية في درجة تمثل الطلبة لقيم

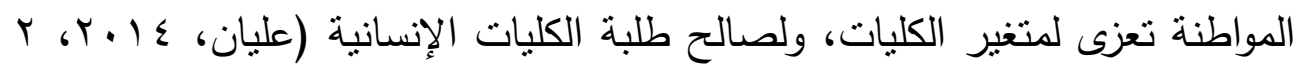
). وأيضّاً تتسق هذه النتيجة مع ما توصلت إليه دراسة (Ramazan,2017, 801) 
من وجود فروقٍ دالةَ في الاتجاهات نحو المواطنة لدى أفراد العينة على وفق تخصصهم الدراسي الرئيس، وأن التخصص الرئيس هو متغير يؤدي دورًاً مهمّاً في

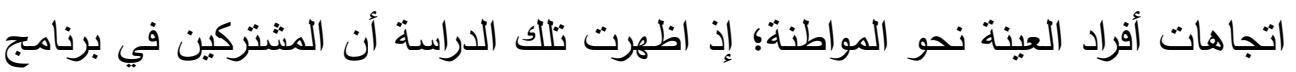
الإعداد التربوي لأقسام العلوم الطبيعية والمشتركين في برنامج الأقسام الإنسانية لديهج فهم مختلف للمواطنة، (Ramazan,2017, 801). ويأتي اتساق نتيجة البحث الحالي مع نتيجة دراسة (Ramazan,2017) منسجمّاً مع الإطار النظري للبحث الحالي والمستقى من (Ramazan,2017) لبلقي الضوء على تفسير نتيجة البحث الحالي التي تقيد بأن الطلبة ذوي التخصصات العلمية يختلفون في فهمه للمواطنة من الطلبة ذوي التخصصات الإنسانية مما يقود إلى تكوين اتجاهات مختلفة لدى التخصصين اتجاه مفهوم المواطنة بوصفه عملية قوامها الواجبات والمسؤوليات المتبادلة بين الدولة والفرد. وهذا الاختلاف في الاتجاهات يتبع الاختلاف في الخصائص الثقافية والاجتماعية.

أظهرت نتائج البحث أن لدى طلبة جامعة بغداد اتجاهات إيجابية نحو مفهوم

المواطنة. وأنه ليس هناك فروق ذات دلاله في اتجاهات طلبة الجامعة نحو مفهوم المواطنة على وفق متغير الجنس. كما أظهرت النتائج وجود فروق ذات دلاله إحصائية في اتجاهات طلبة الجامعة نحو مفهوم المواطنة على وفق متغير التخصص الدراسي؛ إذ إن الطلبة من ذوي التخصص الإنساني لديهم اتجاهات أكثر إيجابية نحو

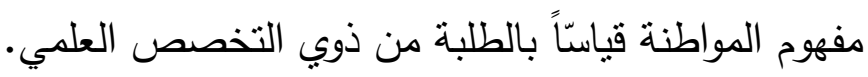


بناءً على نتائج البحث الحالي، خرج الباحث بالتوصيات التالية : 1 - الاستفادة من مقياس اتجاهات طلبة الجامعة نحو مفهوم المواطنة الذي تم بناؤه في البحث الحالي للتعرف على اتجاهات طلبة الجامعات الأخرى نحو المواطنة، ويمكن تقنين المقياس الحالي وتطبيقه على عينات تمثل مراحل دراسية مختلفة أو تمنتل شرائح مختلفة من المجتمع.

r - تسلط الضوء على الاتجاهات الإيجابية لطلبة الجامعة نحو مفهوم المواطنة للعمل على إحداث التأثير الإيجابي في اتجاهات باقي شرائح المجتمع وقطاعات إنجاته المجتمع نحو مفهوم المواطنة. ويمكن أن يتم ذلك من خلال وسائل الإعلام المختلفة ومن خلال الندوات والمؤتمرات التي تعقدها الجامعات والجهات الحكومية ومنظمات المجتمع المدني المعنية بهذا الموضوع.

r - العمل على تعديل اتجاهات الطلبة من ذوي التخصص العلمي لجعلها أكثر إيجابية نحو مفهوم المواطنة، وذللك من خلا البرامج الإرشادية التي تعدها وتقدمها وحدات الإرشاد النفسي في الجامعات لطلبتها.

يقترح الباحث إجراء الدراسات المستقبلية التالية: 1 - إجراء دراسة تستهدف التعرف على اتجاهات شرائح أخرى من المجتمع نحو مفهوم المواطنة ومن هذه الشرائح، شريحة أساتذة الجامعة، والموظفين الحكوميين، والقيادات الإدارية، وأفراد القوات المسلحة وقوى الأمن الوطني. 
r - إجراء دراسة تستهدف التعرف على الفروق في اتجاهات طلبة الجامعة، وغيرهم من شرائح المجتمع، على وفق متغيرات (المستوى الاقتصادي للفرد ، ومستوى التعليم)

r - إجراء دراسة تستهدف التعرف على العلاقة بين الاتجاهات نحو مفهوم المواطنة ومتغيرات (الأمن النفسي ، الرضا عن الحياة والثعور بالانتماء ، وقلق

(المستقبل). 


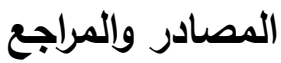

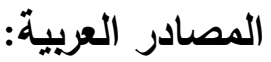

1- دافيدوف ، لندا لـ، . 191 ." مدخل علم النفس - الطبعة الثالثة ". دار ماكجروهيل ـ منشورات مكتبة التحرير .

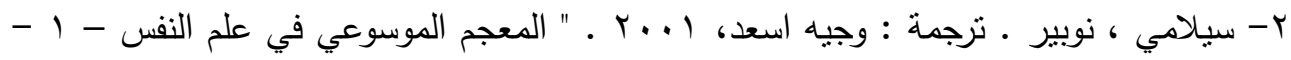

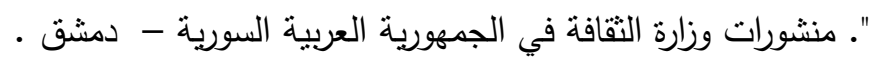

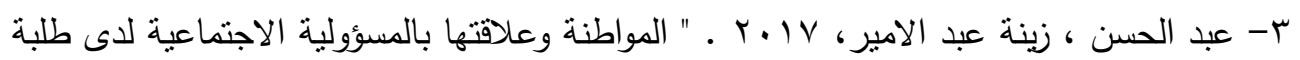

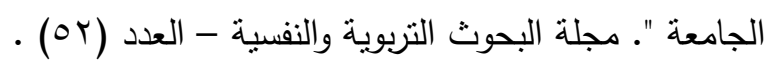

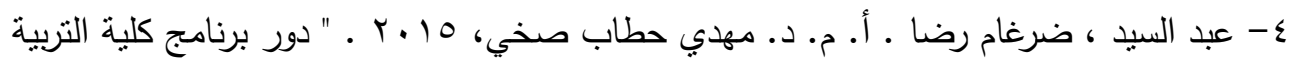

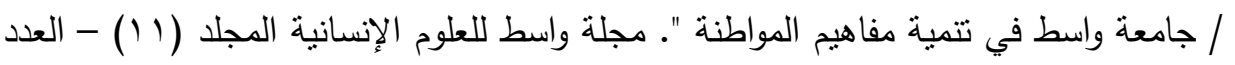

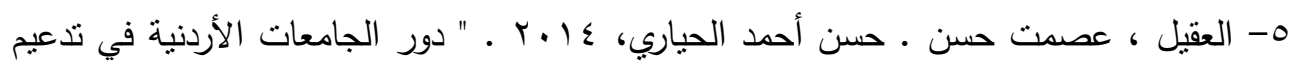

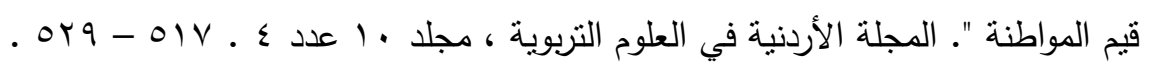

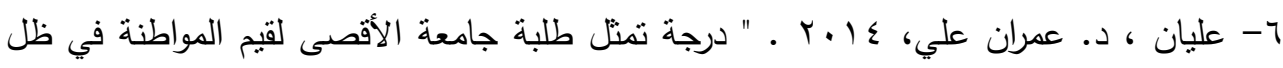

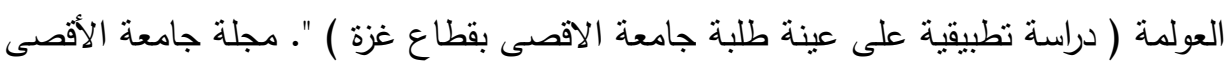

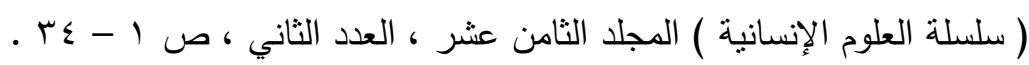

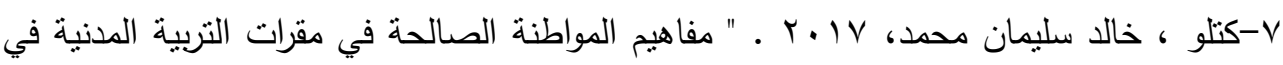
صفوف المرحلة الأساسية العليا في فلسطين ". مجلة كلية فلسطين التقنية للأبحاث والدراسات

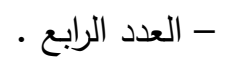

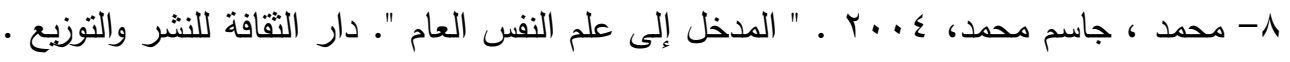

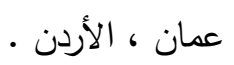

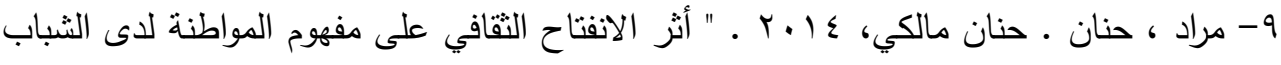
الجزائري ( دراسة ميدانية على عينة من طلبة جامعة محمد خيضر بسكرة ) دراسة استكثافية". مجلة العلوم الإنسانية والإجتماعية، عدد خاص بالملتقى الدولي الأول حول الهوية والمجالات الاجنماعية في ظل التحولات السوسيو - ثقافية في المجنمع الجزائري. 
• 1 - مهدي ، قصير ، 17 ـ ب ـ " مفهوم المواطنة في الددرسة الجزائية - بين التصور والممارسة -

دراسة سوسيولوجية تحليلية بمفاهيم علم الاجتماع السياسي ". أطروحة دكتوراه غير منشورة جامعة وهران r - محمد بن أحمد - كلية العلوم الاجتماعية .

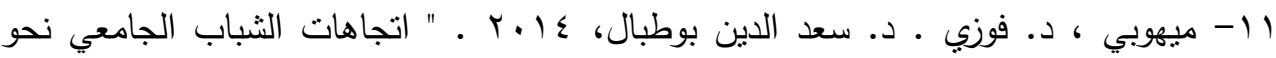

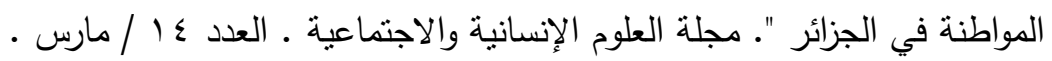
المصادر الاجنبية: - n

1 - Bellamy. Richard, 2013, " Theories of citizenship and their history ", Oxford University Press, https: // doi.org / 10.1093 / act rade / 9780192802538.003.0002.

2 - BREHM,. SHARON S, SAUL M.K, STEVEN. F, 2002," Social Psychology FIFTH Edition ". HOUGTON Mifflin OMPANY.

3 - Passer. M. W, Ronald E. S, 2001," Psychology Frontiers and Applications ". MCGRAW - Hill Higher Education.

4 - Ramazan,. Özbek, Susam Ezlam, 2017, " The evaluation of prospective teachers attitudes to words citizenship and citizenship education. Educational Research and Reviews. VOL. 12 (16). P. $801-810$. 


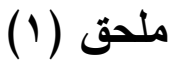

الاستبيان الاستطلاعي لاتجاهات طلبة الجامعة نحو مفهوم المواطنة

\section{عزيزي الطالب - عزيزتي الطالبة}

في نية الباحث القيام ببحث يهذف إلى التعرف على اتجاهات طلبة الجامعة نحو البعائ مفهوم المواطنة. ويعرف الباحث مفهوم المواطنة على أنه ( علاقة الفرد بوطنه

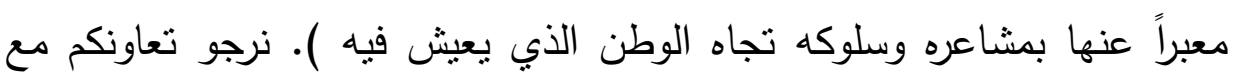
الباحث من خلال تدوينكم لآرائكم ومشاعركم، سواء أكانت إيجابية أم سلبية، اتجاه التهاه

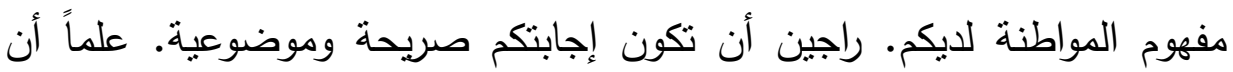
الإجابات لأغراض البحث العلمي، ولا داعي لذكر الاسم ل. .. دع الثنكر.
أنثى
ذكر 0

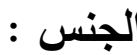
إنساني
علمي 0
التخصص : (الخص

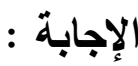




\section{ملحق (r)}

\section{قائمة بأسماء الخبراء}

\begin{tabular}{|c|c|c|}
\hline كلية الآداب / بغداد . & أ. د. أنعام لفت موسى . & 1 \\
\hline كلية الآداب / بغداد ـ & أ. د. كامل علوان الزبيدي . & r \\
\hline كلية الآداب / بغداد ـ & أ. م. د. إبراهيم مرتضى الاعرجي & r \\
\hline كلية الآداب / بغداد ـ & أ. م. د. ثريا علي حسن · & $\varepsilon$ \\
\hline كلية الآداب / المستتصرية . & أ. م. د. رياض عزيز عباس . & 0 \\
\hline كلية الآداب / المستتصرية . & أ. م. د. عباس حسن رويح & 7 \\
\hline كلية الآداب / بغداد . & أ. م. د. عباس حنون الأسدي . & v \\
\hline كلية الآداب / بغداد . & أ. م. د. عبد الحليم رحيم علي . & $\wedge$ \\
\hline كلية الآداب / بغداد . & أ. م. د. علي تركي نافل . & 9 \\
\hline كلية الآداب / بغداد . & أ. م. د. ياسمين جرجيس . & 1. \\
\hline
\end{tabular}




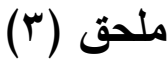

مقياس اتجاهات طلبة الجامعة نحو مفهوم المواطنة بصورته النهائية

أمامك مجموعة من العبارات التي تدور حول بعض مواضيع يمكن أن يتقق

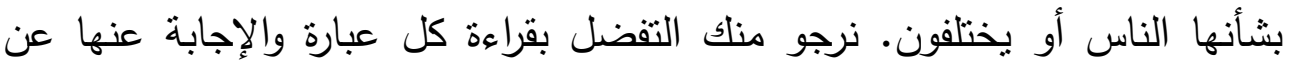
طريق وضع علامة ( ل ) تحت واحد من البدائل الخمسة الموضوعة أمام العبارات

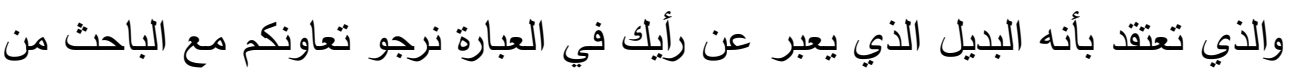

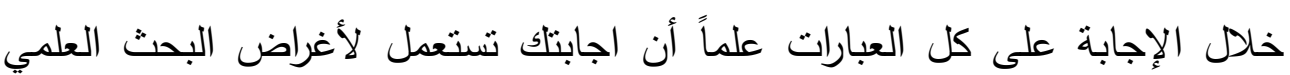
فقط ولا داعي لذكر الأس. وشكراً لتعاونك مع الباحث.

معلومات عامة : - مام
أنثى ( )

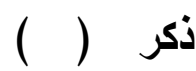

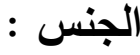

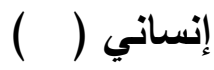
التخصص الدراسي : علمي ( ) 


\begin{tabular}{|c|c|c|c|c|c|c|}
\hline غوافق & غوافق & 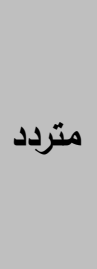 & موافق & موافق & الفقرات & $ت$ \\
\hline & & & & & أشعر أني أحب وطني · & 1 \\
\hline & & & & & 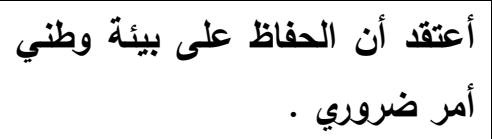 & r \\
\hline & & & & & وطني يطالبني بأكثر مما يقدم لي. & r \\
\hline \multirow[t]{8}{*}{ غلير } & غوافق & 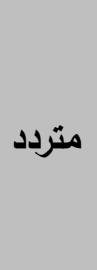 & موافق & موافق & 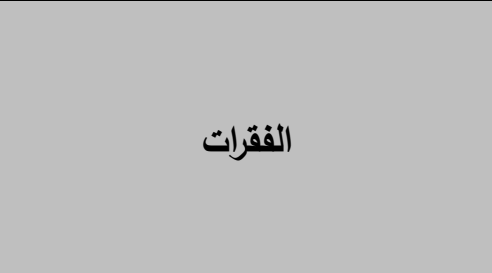 & $ت$ \\
\hline & & & & & التزام الجميع بالقوانين يجعل & $\varepsilon$ \\
\hline & & & & & أحب الحياة في وطني رغم & $\bullet$ \\
\hline & & & & & 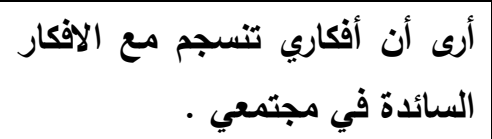 & 7 \\
\hline & & & & & من انتمائي لمنطقتي ولعشيرتي أهم & $v$ \\
\hline & & & & & أثُعر بالرضا عن وطني · & $\Lambda$ \\
\hline & & & & & أؤمن بأهمية واجبي تجاه وطني · & 9 \\
\hline & & & & & الالانتماء للوطن فوق كل & 1. \\
\hline & & & & & الواجبات اكثر من الحقوق في & 11 \\
\hline
\end{tabular}




\begin{tabular}{|c|c|c|c|c|c|c|}
\hline & & & & & وطني · & \\
\hline & & & & & لا أتردد في تقديم أي شيء في & Ir \\
\hline & & & & & انتمائي لوطني يشعرني بالفخر · & ir \\
\hline & & & & & 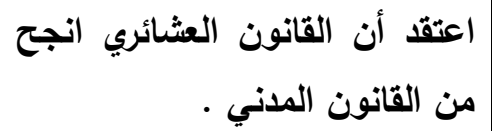 & $1 \varepsilon$ \\
\hline & & & & & أفضل . الاهتمام بالبيئة يجعل الوطن مكاناً & 10 \\
\hline & & & & & الا مانع من امتلاك جهات غير & 17 \\
\hline \multirow[t]{8}{*}{ غوافي } & غوافق & متردد & موافق & موافق & الفقرات & $ت$ \\
\hline & & & & & أتتنى أن أهاجر من وطني . & iv \\
\hline & & & & & 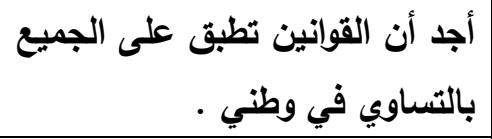 & 11 \\
\hline & & & & & أني أحبه ـ لصعية الحياة في وطني، لا أثبر & 19 \\
\hline & & & & & أعقق أني أتمتع بالكثير من & r. \\
\hline & & & & & القدالة . القين في وطني تضمن وجود & Y \\
\hline & & & & & أعتقد أن قانون الدولة الرسمي هو & r \\
\hline & & & & & أشعر بالغربة في وطني · & $r r$ \\
\hline
\end{tabular}




\begin{tabular}{|c|c|c|c|c|c|c|}
\hline & & & & & على جميع تحمل مسؤولياتهم تجاه & Y $\varepsilon$ \\
\hline & & & & & 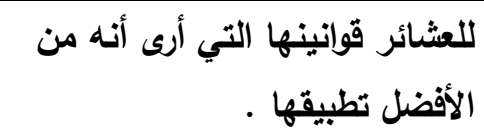 & ro \\
\hline & & & & & وطثني · بأنه ليس لي مستقبل في & Y \\
\hline & & & & & تدعي وطني العديد من الرموز التي & rv \\
\hline & & & & & ثي واجبات يجب أن يقدمها التي يقدها الفرد للوطن & r^ \\
\hline \multirow[t]{7}{*}{ غوافق } & غوافق & 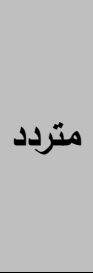 & موافق & موافق & الفقرات & $ت$ \\
\hline & & & & & كثثرًاً ما أشعر بعدم الرضا عن & rq \\
\hline & & & & & 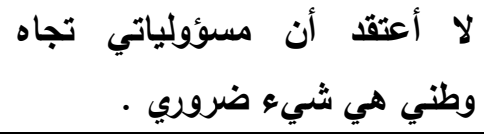 & r. \\
\hline & & & & & سيكون لي مستقبل جيد في وطني & ו \\
\hline & & & & & فقط . القوانين يجب أن تطبقها الدولة & $r r$ \\
\hline & & & & & أشيش فيش الألفة في المجتمع الأي & r \\
\hline & & & & & مصلحتي الشخصية أهم من & $r \varepsilon$ \\
\hline
\end{tabular}




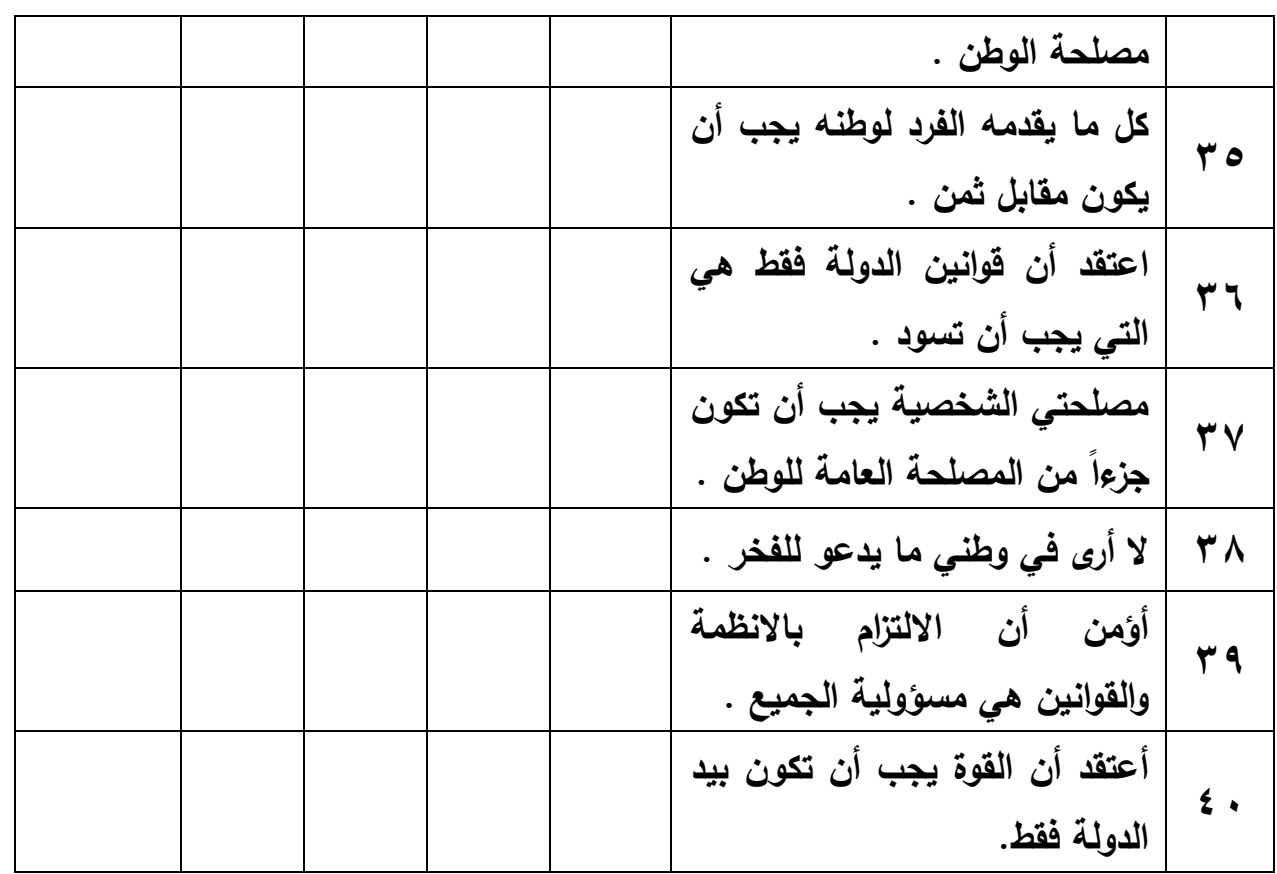

